\title{
HANDBOOK of Fruit \\ and Vegetable Flavors
}

Edited by:

Y.H. Hui

\section{Technical Editors:}

Feng Chen and L.M.L. Nollet

\section{Associate Editors:}

Raquel P. F. Guiné, Olga Martin-Belloso,

M. Isabel Mínguez-Mosquera, Gopinadhan Paliyath,

Fernando L. P. Pessoa, Jean-Luc Le Quéré, Jiwan S. Sidhu, Nirmal Sinha, Peggy Stanfield

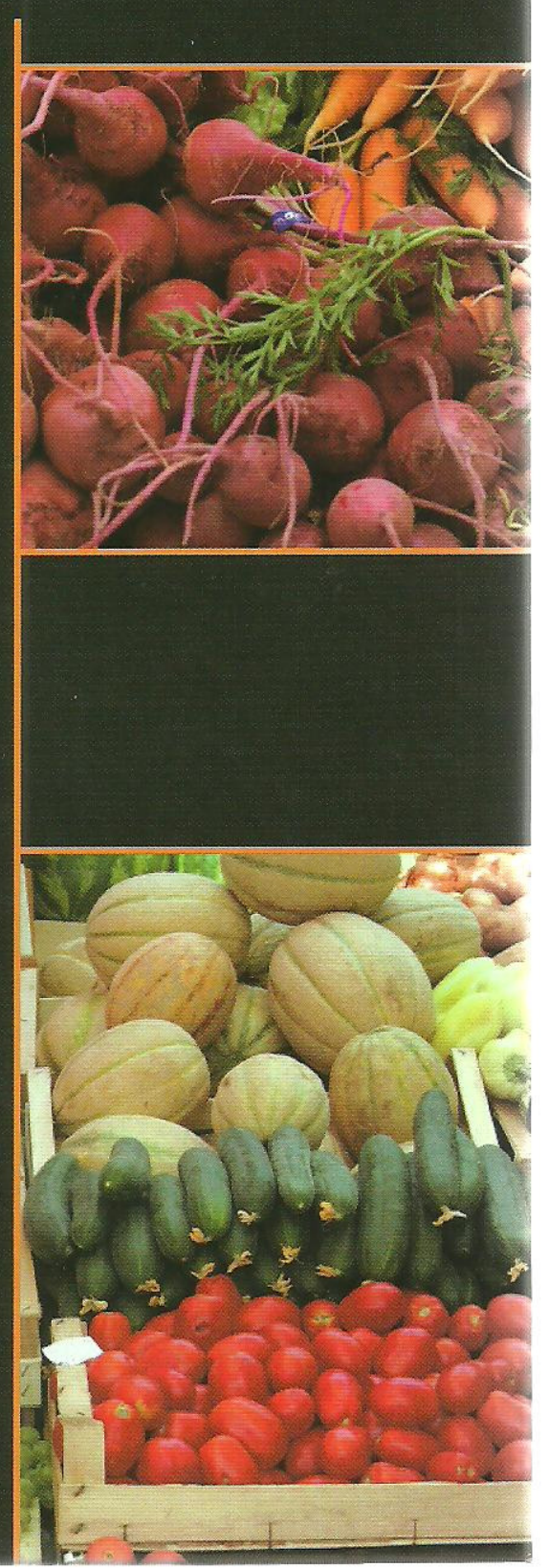




\section{A global PERSPECTIVE on the latest SCIENCE, TEGHNOLOGY, and APPLIGATIONS}

The demand for new flavors continues to rise. Today's consumers want interesting, healthy, pleasurable, and exciting taste experiences, creating new challenges for today's food and flavor scientists. Fortunately, they can turn to this comprehensive reference on the flavor science and technology of fruits, vegetables, spices, and oils for guidance on everything from basic science to new technologies to commercialization.

Handbook of Fruit and Vegetable Flavors is divided into two sections. The first section, dedicated to fruit flavor, is organized into five parts:

- Part I: Biology, Chemistry, and Physiochemistry

- Part ll: Biotechnology

- Part III: Analytic Methodology and Chemical Characterizations

- Part IV: Flavors for Fruit Commodities

- Part V: Flavors of Selected Dried Fruits

The second section, dedicated to vegetable flavor, is divided into two parts, covering biology, chemistry, physiochemistry, and biotechnology in the first part and flavor for vegetable commodities in the second part. Both the fruit flavor and vegetable flavor sections provide detailed coverage of such important topics as processing, extraction, flavor biosynthesis, and genetic engineering. Moreover, readers will find important details on regulations and requirements governing flavor additives as well as sanitation and saffety in flavor manufacturing.

Each of the chapters has been written by one or more leading experts in food and flavor science. The authors represent more than ten countries, giving food and flavor scientists a unique global perspective on the latest flavor science, technology, and applications.

Y. H. HUI, PHD, is the Senior Scientist at Science Technology System and has been the author and editor of many books in the field of food science and technology.

Subscribe to our free Chemistry eNewsletter at

wiley.com/enewsletters

Visit wiley.com/chemistry 


\section{HANDBOOK OF FRUIT AND VEGETABLE FLAVORS}

Edited by

Y.H. Hui

Science Technology System

Technical Editors

\section{Feng Chen}

Department of Food Science and Human Nutrition Clemson University

\section{Associate Editors}

Raquel P.F. Guiné

Departamento de Indústrias Agro-Alimentares Escola Superior Agrária de Viseu

M. Isabel Mínguez-Mosquera Food Biotechnology Department Instituto de la Grasa (CSIC)

\section{Fernando L.P. Pessoa}

Depart de Engenharia Química, Escola de Química

Univ Federal do Rio de Janeiro

Jiwan S. Sidhu

Department of Family Science

Kuwait Women University

Peggy Stanfield

Consultant
L.M.L. Nollet

Department of Engineering

Hogeschool Gent

\section{Olga Martín-Belloso}

Department of Food Technology University of Lleida

Gopinadhan Paliyath

Department of Plant Agriculture University of Guelph.

Jean-Luc Le Quéré

Institut National de la Recherche Agronomique (INRA)

Unité Mixte de Recherche sur les Arômes (UMRA)

Nirmal Sinha

Research and Development Graceland Fruit, Inc.

\section{(3)WILEY}

A JOHN WILEY \& SONS, INC., PUBLICATION 
Copyright $\odot 2010$ by John Wiley \& Sons, Inc. All rights reserved

Published by John Wiley \& Sons, Inc., Hoboken, New Jersey Published simultaneously in Canada

No part of this publication may be reproduced, stored in a retrieval system, or transmitted in any form or by any means, electronic, mechanical, photocopying, recording, scanning, or otherwise, except as permitted under Section 107 or 108 of the 1976 United States Copyright Act, without either the prior written permission of the Publisher, or authorization through payment of the appropriate per-copy fee to the Copyright Clearance Center, Inc., 222 Rosewood Drive, Danvers, MA 01923, (978) 750-8400, fax (978) $750-4470$, or on the web at www.copyright.com. Requests to the Publisher for permission should be addressed to the Permissions Department, John Wiley \& Sons, Inc., 111 River Street, Hoboken, NJ 07030, (201) 748-6011, fax (201) 748-6008, or online at http://www.wiley.com/go/ permission.

Limit of Liability/Disclaimer of Warranty: While the publisher and author have used their best efforts in preparing this book, they make no representations or warranties with respect to the accuracy or completeness of the contents of this book and specifically disclaim any implied warranties of merchantability or fitness for a particular purpose. No warranty may be created or extended by sales representatives or written sales materials. The advice and strategies contained herein may not be suitable for your situation. You should consult with a professional where appropriate. Neither the publisher nor author shall be liable for any loss of profit or any other commercial damages, including but not limited to special, incidental, consequential, or other damages.

For general information on our other products and services or for technical support, please contact our Customer Care Department within the United States at (800) 762-2974, outside the United States at (317) 572-3993 or fax (317) 572-4002.

Wiley also publishes its books in a variety of electronic formats. Some content that appears in print may not be available in electronic formats. For more information about Wiley products, visit our web site at www.wiley.com.

\section{Library of Congress Cataloging-in-Publication Data:}

Handbook of fruit and vegetable flavors / edited by Y.H. Hui. p. $\mathrm{cm}$.

Summary: "Acting as chemical messengers for olfactory cells, food flavor materials are organic compounds that give off a strong, typically pleasant smells. Handbook of Fruit and Vegetable Flavors explores the flavor science and technology of fruits and vegetables, spices, and oils by first introducing specific flavors and their commercialization, then detailing the technical aspects, including biology, biotechnology, chemistry, physiochemistry, processing, analysis, extraction, commodities, and requirements for application as food additives. With chapter authors representing more than ten different countries, this handy reference provides a comprehensive view of this evolving science." Provided by publisher.

Summary: "This book provides a comprehensive reference on the flavor science and technology of fruits and vegetables, spices, and oils. Beginning with an introduction on the specific flavors and their commercialization, the book then details the technical aspects including biology, biotechnology, chemistry, physiochemistry, processing, analysis, extraction, commodities, and requirements for application as food additives. Regulatory considerations are discussed in relation to sanitation and safety in a flavor manufacturing establishment" - Provided by publisher.

ISBN 978-0-470-22721-3 (hardback)

1. Fruit-Flavor and odor-Handbooks, manuals, etc. 2. Vegetables-Flavor and odor-Handbooks, manuals, etc. 3. Oils and fats-Flavor and odor-Handbooks, manuals, etc. 4. Food-Sensory evaluation-Handbooks, manuals, etc. I. Hui, Y. H. (Yiu H.)

TP440.H357 2010

$664^{\prime} .5-\mathrm{dc} 22$

Printed in the United States of America

$\begin{array}{lllllllllll}10 & 9 & 8 & 7 & 6 & 5 & 4 & 3 & 2 & 1\end{array}$ 
PREFACE

CONTRIBUTORS xiii

LIST OF ABBREVIATIONS Xix

SECTION A: FRUIT FLAVORS

PART I FRUIT FLAVORS: BIOLOGY, CHEMISTRY, AND PHYSIOCHEMISTRY 1

1. Fruits and Fruit Flavor: Classification and Biological Characterization 3 Yueming Jiang and Jun Song

2. Physiology and Biochemistry of Fruit Flavors ' 25

Sonia Osorio, Cristina Muñoz, and Victoriano Valpuesta

3. Sensory Evaluation of Fruit and Vegetable Flavors 45

Sara Bayarri and Elvira Costell

4. Fermentation and Fruit Flavor Production

Gabriela Alves Macedo, Juliana Alves Macedo, and Luciana Francisco Fleuri

5. Environmental Effects on Flavor Changes 73

Clara Pelayo-Zaldívar

\section{PART II FRUIT FLAVORS: BIOTECHNOLOGY 93}

6. Cell Culture for Flavor Production $\quad 95$

Adriane B.P. Medeiros, Suzan C. Rossi, and Carlos R. Soccol

7. Genetic Engineering of Fruit Flavors 101

Asaph Aharoni and Efraim Lewinsohn

8. Bioconversion of Flavors

P.F.F. Amaral, M.H.M. Rocha-Leão, and M.A.Z. Coelho

9. Plant Metabolic Pathways and Flavor Biosynthesis

Carlos Sanz and Ana G. Pérez.

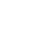

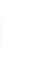

5


PART III FRUIT FLAVORS: ANALYTIC METHODOLOGY AND

10. History and Principles of Flavor Analysis

F. Gutiérrez-Rosales

11. Advanced Analytic Methodology Jean-Luc Le Quéré

12. Extraction and Distillation

Fernando L.P. Pessoa, Marisa F. Mendes, Eduardo M. Queiroz, and Silvio A.B. Vieira De Melo

13. Flavor Extraction: Headspace, SDE, or SFE

Gerson L.V. Coelho, Marisa F. Mendes, and Fernando L.P. Pessoa

PART IV FLAVORS FOR FRUIT COMMODITIES

14. Annona Fruits Jorge A. Pino

15. Apple (Malus $\times$ domestica Borkh.) Maria Luisa López Fructuoso and Gemma Echeverría Cortada

16. Citrus Fruits and Oranges

L.M.C. Cabral, A. Bravo, M. Freire JR., H.R. Bizzo, and V.M. Matta

17. Flavor in Grapes: Its Characterization and Commercial Applications N.R. Bhat, B.B. Desai, and M.K. Suleiman

18. The Aroma of Wine Juan Cacho and Vicente Ferreira

19. Mango Flavor

Narendra Narain, Nisha Nigam, and Mércia de Sousa Galvão

21. Pineapple (Ananas comosus [L.] Merril) Flavor

Marta Montero-Calderón, M. Alejandra Rojas-Graü, and Olga Martín-Belloso

22. The Flavor of Plums

E. Gómez-Plaza and C. Ledbetter 
24. Temperate Fruit Juice Flavors

Terri D. Boylston

25. Fruits from Central and South America

Jiwan S. Sidhu and Yearul Kabir

\section{PART V FLAVORS OF SELECTED DRIED FRUITS}

26. Overview of Flavors and Fruit Dehydration

Regina Nabais

27. Flavors of Dried Apples

Elena Venir

28. Flavors of Dried Apricots

Mustafa Z. Özel and Fahrettin Göğüş

Juan Wang, Bing Du, and Gong Ming Yang

30. Volatile Aroma/Flavor Components of Raisins (Dried Grapes) Ron G. Buttery

31. Flavors of Dried Pears

Draženka Komes and Karin Kovačević Ganić

SECTION B: VEGETABLE FLAVORS

PART VI VEGETABLE FLAVORS: BIOLOGY, CHEMISTRY, PHYSIOCHEMISTRY, AND BIOTECHNOLOGY

32. Chemistry and Biochemistry of Some Vegetable Flavors

Qayyum Husain

33. Traditional and New Analytical Methodology

Emira Mehinagic and Jean-Luc Le Quéré

34. Vegetable Flavors from Cell Culture

María Asunción Longo and María Angeles Sanromán

35. Flavor from Transgenic Vegetables

Moustapha Oke and Gopinadhan Paliyath

36. Genetic Engineering of Fruit Flavors

Jingyu Lin, Ningning Wang, Vincent P. Pantalone, and Feng Chen

37. Metabolic Factory for Flavors in Fruits and Vegetables 
viii CONTENTS

PART VII VEGETABLE COMMODITIES

38. Avocado (Persea Americana Mill.) Oil

Suely P. Freitas, Neusa P. Arruda, Clarice N. Gobbi, and

Cláudia M. De Resende

39. Cabbage Flavor

Theodore J.K. Radovich

Ahmad Sulaeman and Judy A. Driskell

P.S. Raju, O.P. Chauhan, and A.S. Bawa

Linda Pollak

Diego Luis García-González, María Teresa Morales, and Ramón Aparicio

44. Flavors in Onion: Characterization and Commercial Applications N.R. Bhat, B.B. Desai, and M.K. Suleiman

45. Onion: A Food, Spice, and Remedy in the Middle Eastern Gastronomy

Pervin Basaran and Nese-Basaran-Akgul

Nese B. Akgul, Pervin Basaran, and Jiwan S. Sidhu

47. Flavoring Compounds in Red Pepper Fruits (Capsicum genus) and Processed Products

Elisabet Fernández-García and Antonio Pérez-Gálvez

48. Potato Flavor

Shelley H. Jansky

49. Mexican Pickled Jalapeño Pepper

María Eugenia Jaramillo-Flores, Lidia Dorantes-Alvarez,

Raquel García-Barrientos, and Jorge Welti-Chanes

50. Dried Western Vegetable Products 
51. Understanding Peanut Flavor: A Current Review E.R. Neta, T. Sanders, and M.A. Drake

52. Spices, Seasonings, and Essential Oils Marisa F. Mendes and Fernando L.P. Pessoa

53. Flavor of Canola Oil Silvana Martini

Ainie Kuntom and Abd. Azis Ariffin

1071

Neusa P. Arruda, Cláudia M. de Resende, and Suely P. Freitas 
For the last 50 years, our knowledge of the science and technology of food flavors has increased tremendously. To distribute the information, publishers have released many professional reference books on the subject. In general, most of the books have some discussion on the flavors of fruits and vegetables, though several of them specifically address these two important groups of food commodities. Information on the flavors of fruits and vegetables is essential to the work of government, academia, and industry. This book is an updated reference treatise on the flavors of fruits and vegetables. It includes 55 chapters, with 31 on the flavor of fruits and 24 on that of vegetables, covering the following topics:

- biology, chemistry, and biochemistry

- biotechnology and genetic engineering

- analytical methodology

- processing technology

- fresh and processed commodities

- products derived from processed fruits and vegetables

- regulatory consideration

There are several professional books on the subject matter and the preference for any particular one depends on the needs of the users. Although many topics are included in this volume, we do not claim that the coverage is comprehensive.

This work is the result of the combined efforts of more than 70 individuals from industry, government and academia worldwide. They represent the expertise of professionals from 18 countries including Belgium, Brazil, China, Canada, Croatia, Cuba, France, India, Indonesia, Israel, Italy, Japan, Kuwait, Malaysia, Mexico, Portugal, Spain, Turkey, and the United States. The editorial team consists of 12 established experts in the flavors or processing of fruits and vegetables. Each contributor or editor was responsible for researching and reviewing subjects of immense depth, breadth, and complexity. Care and attention were paramount to ensure technical accuracy for each topic. In sum, this volume is unique in many respects. It is our sincere hope and belief that it will serve as an essential reference on the flavors of major plant foods.

We wish to thank all the contributors for sharing their expertise throughout our journey. We also thank the reviewers for giving their valuable comments leading to 
improvements in the contents of each chapter. In addition, we thank members of the production team at John Wiley and Sons for their time, effort, advice, and expertise. All these professionals are the ones who made this book possible. You are the best judge of the quality of their work and we trust that you will benefit from the fruits of their labor.

Y. H. HuI

F. CHEN

L. M. L. Nollet

R. P. F. GUINÉ

J. L. Le Quéré

O. Martín-Belloso

M. I. Mínguez-MosQuera

G. Paliyath

F. L. P. PESSOA

J. S. SiDHU

N. SINHA

P. STANFIELD 
Nese B.Agkul, Department of Food Engineering, Faculty of Engineering, Hacettepe University, Ankara, Turkey

Asaph Aharoni, Department of Plant Sciences, Weizmann Institute of Science, Rehovot, Israel

P.F.F. Amaral, Departamento de Engenharia Bioquímica, Escola de Químical UFRJ, Rio de Janeiro, Brazil

Ramón Aparicio, Instituto de la Grasa, Padre García Tejero, Seville, Spain

Abd. Azis Ariffin, Malaysian Palm Oil Board, Kuala Lumpur, Malaysia

Neusa P. Arruda, Instituto Federal do Rio de Janeiro, Rio de Janeiro, Brazil

Pervin Basaran, Department of Food Engineering, Suleyman Demirel University, Cunur, Isparta, Turkey

A.S. Bawa, Defence Food Research Laboratory, Siddarthanagar, Mysore, India

Sara Bayarri, Instituto de Agroquímica y Tecnología de Alimentos, CSIC, Burjassot, Valencia, Spain

N.R. Bhat, Aridland Agriculture and Greenery Department, Food Resources and Marine Sciences Division, Kuwait Institute for Scientific Research, Safat, Kuwait

H.R. Bizzo, Embrapa Agroindústria de Alimentos, Av. das Américas, Rio de Janeiro, Brazil

Terri D. Boylston, Department Food Science \& Human Nutrition, Iowa State University, Ames, IA

A. Bravo, Curso de Pós-graduação em Ciência de Alimentos, Instituto de Química/ UFRJ, Rio de Janeiro, Brazil

Ron G. Buttery, U.S. Department of Agriculture, Agricultural Research Service, Western Regional Research Center, Albany, CA

L.M.C. Cabral, Embrapa Agroindústria de Alimentos, Rio de Janeiro, Brazil

Jan Cacho, Laboratory for Flavor Analysis and Enology, Aragon Institute of Engineering Research, Analytical Chemistry Department, Faculty of Sciences, University of Zaragoza, Zaragoza, Spain 
O.P. Chauhan, Defence Food Research Laboratory, Siddarthanagar, Mysore, India

Feng Chen, Department of Plant Sciences, University of Tennessee, Knoxville, TN

Gerson L.V. Coelho, Departamento de Engenharia Química, Escola de Química, Universidade Federal do Rio de Janeiro, Rio de Janeiro, Brazil

M.A.Z. Coelho, Departamento de Engenharia Bioquímica, Escola de Química/ UFRJ, Rio de Janeiro, Brazil

Gemma Echeverría Cortada, Postharvest Department, IRTA, Lleida, Spain

Elvira Costell, Instituto de Agroquímica y Tecnología de Alimentos, CSIC, Burjassot, Valencia, Spain

Cláudia M. de Resende, Universidade Federal do Rio de Janeiro, Instituto de Química, Rio de Janeiro, Brazil

B.B. Desai, Aridland Agriculture and Greenery Department, Food Resources and Marine Sciences Division, Kuwait Institute for Scientific Research, Safat, Kuwait

Mércia de Sousa Galvão, Laboratório de Análise de Flavor, Núcleo de PósGraduação em Ciência e Tecnologia de Alimentos, Universidade Federal do Sergipe, São Cristóvão-SE, Brazil

Lidia Dorantes-Alvarez, Escuela Nacional de Ciencias Biológicas-IPN, Departamento de Graduados en Alimentos, Carpio y Plan de Ayala, Mexico, D.F.

M.A. Drake, Department of Food, Bioprocessing and Nutrition Sciences, North Carolina State University, Raleigh, NC

Judy A. Driskell, Department of Community Nutrition, Faculty of Human Ecology, Bogor Agricultural University (IPB), Indonesia; and Department of Nutrition and Health Sciences, University of Nebraska-Lincoln, Lincoln, NE

Bing Du, College of Food Science, South China Agricultural University, Guangzhou, China

Elisabet Fernández-García, Grupo de Química y Bioquímica de Pigmentos, Departamento de Biotecnología de Alimentos, Instituto de la Grasa (CSIC), Seville, Spain

Vicente Ferreira, Laboratory for Flavor Analysis and Enology, Aragon Institute of Engineering Research, Analytical Chemistry Department, Faculty of Sciences, University of Zaragoza, Zaragoza, Spain

Luciana Francisco Fleuri, Lab. de Bioquimica de Alimentos, DCA-FEAUNICAMP, Campina SP, Brazil

M. Freire, Jr., Embrapa Agroindústria de Alimentos, Rio de Janeiro, Brazil

Suely P. Freitas, Universidade Federal do Rio de Janeiro, Escola de Química, Rio de Janeiro, Brazil 
Maria Luisa López Fructuoso, Department of Food Technology, University of Lleida, Lleida, Spain

Karin Kovačević Ganić, Faculty of Food Technology and Biotechnology, University of Zagreb, Zagreb, Croatia

Raquel García-Barrientos, Universidad Autónoma Metropolitana--Unidad Iztapalapa, Mexico, D.F.

Diego Luis García-González, Instituto de la Grasa, Padre García Tejero, Seville, Spain

Clarice N. Gobbi, Universidade Federal do Rio de Janeiro, Escola de Química, Rio de Janeiro, Brazil

Fahrettin Göğüs, The University of Pamukkale, Faculty of Science \& Arts, Chemistry Department, Denizli, Turkey

E. Gómez-Plaza, Food Science and Technology Department, University of Murcia, Murcia, Spain

F. Gutiérrez-Rosales, Instituto de la Grasa (CSIC), Seville, Spain

Qayyum Husain, Department of Biochemistry, Faculty of Life Sciences, A.M.U. Aligarh, India

Yoko lijima, Kazusa DNA Research Institute, Kisarazu, Japan

Shelley H. Jansky, USDA-ARS and Department of Horticulture, University of Wisconsin-Madison, Madison, WI

María Eugenia Jaramillo-Flores, Escuela Nacional de Ciencias Biológicas-IPN, Departamento de Graduados en Alimentos, Carpio y Plan de Ayala, Mexico, D.F.

Yueming Jiang, South China Botanical Garden, Chinese Academy of Sciences, Guangzhou, China

Yearul Kabir, Department of Biochemistry and Molecular Biology, University of Dhaka, Dhaka, Bangladesh

Draženka Komes, Faculty of Food Technology and Biotechnology, University of Zagreb, Zagreb, Croatia

Ainie Kuntom, Malaysian Palm Oil Board, Kuala Lumpur, Malaysia

C. Ledbetter, Crop Diseases, Pests \& Genetics Research Unit, USDA, ARS, Parlier, CA

Jean-Luc Le Quéré, Institut National de la Recherche Agronomique (INRA), UMR 1129 Flavor, Vision and Consumer Behavior (FLAVIC), Dijon, France

Efraim Lewinsohn, Newe Yaar Research Center, Agricultural Research Organization, Ramat Yishay, Israel

Jingyu Lin, Department of Plant Sciences, University of Tennessee, Knoxville, TN 
María Asunción Longo, Department of Chemical Engineering, University of Vigo, Campus Universitario As Lagoas, Marcosende, Vigo, Spain

Gabriela Alves Macedo, Lab. de Bioquimica de Alimentos, DCA-FEA-UNICAMP, Campina SP, Brazil

Juliana Alves Macedo, Lab. de Bioquimica de Alimentos, DCA-FEA-UNICAMP, Campina SP, Brazil

Olga Martín-Belloso, Department of Food Technology, University of Lleida, Lleida, Spain

Silvana Martini, Department of Nutrition and Food Sciences, Utah State University, Logan, UT

V.M. Matta, Embrapa Agroindústria de Alimentos, Av. das Américas, Rio de Janeiro, Brazil

Adriane B.P. Medeiros, Divisão de Engenharia de Bioprocessos and Biotecnologia, Departamento de Engenharia Química, Universidade Federal do Paraná, Curitiba, PR, Brazil

Emira Mehinagic, Groupe ESA, Laboratory GRAPPE, Angers, France

Marisa F. Mendes, Laboratório de Termodinâmica Aplicada/Departamento de Engenharia Química, Universidade Federal Rural do Rio de Janeiro, Seropédica, Rio de Janeiro, Brazil

Marta Montero-Calderón, Department of Food Technology, University of Lleida, Lleida, Spain

María Teresa Morales, Facultad de Farmacia, Universidad de Sevilla, Seville, Spain

Cristina Muñoz, Departamento de Biología Molecular y Bioquímica, Universidad de Málaga, Málaga, Spain

Regina Nabais, CERNAS - Centro de Recursos Naturais, Ambiente e Sociedade, Escola Superior Agrária de Coimbra, Instituto Politécnico de Coimbra, Bencanta, Coimbra, Portugal

Narendra Narain, Laboratório de Análise de Flavor, Núcleo de Pós-Graduação em Ciência e Tecnologia de Alimentos, Universidade Federal do Sergipe, São Cristóvão-SE, Brazil

E.R.D. Neta, Department of Food, Bioprocessing and Nutrition Sciences, North Carolina State University, Raleigh, NC

Nisha Nigam, Department of Chemistry, R.D. National College, Bandra-West, Mumbai, India

Leo Nollet, University College Ghent, Member of Ghent University Association, Faculty of Applied Engineering Sciences, Ghent, Belgium

Moustapha Oke, Ontario Ministry of Agriculture, Food and Rural Affairs, Guelph, Ontario, Canada 
Sonia Osorio, Departamento de Biología Molecular y Bioquímica, Universidad de Málaga, Málaga, Spain

Mustafa Z. Özel, The University of Pamukkale, Faculty of Science \& Arts, Chemistry Department, Denizli, Turkey

Gopinadhan Paliyath, Department of Plant Agriculture, University of Guelph, Guelph, Ontario, Canada

Vincent R. Pantalone, Department of Plant Sciences, University of Tennessee, Knoxville, TN

Clara Pelayo-Zaldívar, Food Sciences, Department of Biotechnology, Universidad Autónoma Metropolitana-Iztapalapa, Mexico

Ana G. Pérez, Department of Physiology and Technology of Plant Products, Instituto de la Grasa, CSIC, Seville, Spain

Antonio Pérez-Gálvez, Grupo de Química y Bioquímica de Pigmentos, Departamento de Biotecnología de Alimentos, Instituto de la Grasa (CSIC), Seville, Spain

Fernando L.P. Pessoa, GIPQ/DEQ/EQ/UFRJ, CT, Rio de Janeiro, Brazil

Jorge A. Pino, Instituto de Investigaciones para la Industria Alimentaria, Havana, Cuba

Linda Pollak, USDA-ARS Corn Insects and Crop Genetics Research Unit, Ames, IA

Eduardo M. Queiroz, Departamento de Engenharia Química, Escola de Química, Universidade Federal do Rio de Janeiro, Rio de Janeiro, Brazil

Theodore J.K. Radovich, Department of Tropical Plant and Soil Sciences, University of Hawai'i at Mānoa, Honolulu, HI

P.S. Raju, Defence Food Research Laboratory, Siddarthanagar, Mysore, India

M.H.M. Rocha-Leão, Departamento de Engenharia Bioquímica, Escola de Química/UFRJ, Rio de Janeiro, Brazil

M. Alejandra Rojas-Graii, Department of Food Technology, University of Lleida, Lleida, Spain

Suzan C. Rossi, Divisão de Engenharia de Bioprocessos \& Biotecnologia, Departamento de Engenharia Química, Universidade Federal do Paraná, Curitiba, PR, Brazil

T.H. Sanders, United States Department of Agriculture, Agricultural Research Service, Market Quality and Handling Research Unit, Raleigh, NC

María Angeles Sanromán, Department of Chemical Engineering, University of Vigo, Campus Universitario As Lagoas, Marcosende, Vigo, Spain

Carlos Sanz, Department of Physiology and Technology of Plant Products, Instituto de la Grasa, CSIC, Seville, Spain 
Jiwan S. Sidhu, Department of Family Sciences, College for Women, Kuwait University, Safat, Kuwait

Carlos R. Soccol, Divisão de Engenharia de Bioprocessos \& Biotecnologia, Departamento de Engenharia Química,Universidade Federal do Paraná, Curitiba, PR, Brazil

Jun Song, Agriculture and Agri-Food Canada, Atlantic Food and Horticulture Research Centre, Kentville, Nova Scotia, Canada

Ahmad Sulaeman, Department of Community Nutrition, Faculty of Human Ecology, Bogor Agricultural University (IPB), Indonesia; and Department of Nutrition and Health Sciences, University of Nebraska-Lincoln, Lincoln, NE

M.K. Suleiman, Aridland Agriculture and Greenery Department, Food Resources and Marine Sciences Division, Kuwait Institute for Scientific Research, Safat, Kuwait

Victoriano Valpuesta, Departamento de Biología Molecular y Bioquímica, Universidad de Málaga, Málaga, Spain

Elena Venir, Department of Food Science, University of Udine, Udine, Italy

Silvio A.B. Vieira de Melo, Programa de Engenharia Industrial, Escola Politécnica, Universidade Federal da Bahia, Salvador-BA, Brazil

Juan Wang, College of Light Industry and Food Sciences, South China University of Technology, Guangzhou, China; and College of Food Science, South China Agricultural University, Guangzhou, China

Ningning Wang, College of Life Sciences, Nankai University, Tianjin, China

Jorge Welti-Chanes, Instituto Tecnológico y de Estudios Superiores de MonterreyCampus Monterrey, Mexico, D.F.

Gong Ming Yang, College of Food Science, South China Agricultural University, Guangzhou, China 